\title{
Ovarian Development and Vitellogenin Gene Expression under Heat Stress in Silkworm, Bombyx mori
}

\author{
Satinath Paul and Bela Keshan \\ Department of Zoology, North-Eastern Hill University, Shillong, Meghalaya 793022, India \\ Correspondence should be addressed to Bela Keshan; bkeshan@hotmail.com
}

Received 1 April 2016; Revised 19 July 2016; Accepted 27 July 2016

Academic Editor: Vladimir Kostal

Copyright (C) 2016 S. Paul and B. Keshan. This is an open access article distributed under the Creative Commons Attribution License, which permits unrestricted use, distribution, and reproduction in any medium, provided the original work is properly cited.

\begin{abstract}
The present study observed the effect of heat stress on ovarian development, fecundity, and vitellogenin gene expression in silkworm, Bombyx mori. The result showed that the heat shock treatment to spinning larvae and pupae at $39^{\circ} \mathrm{C}(1 \mathrm{~h}$ and $2 \mathrm{~h})$ did not cause any adverse effect on the reproductive performance of $B$. mori. However, the heat shock treatment at $42^{\circ} \mathrm{C}$ or above caused a decrease in the fecundity. The heat shock treatment to day 2 pupae for $2 \mathrm{~h}$ at $45^{\circ} \mathrm{C}$ caused a drastic effect on the development of ovary as measured by gonadosomatic index. The study thus showed that a brief exposure of Bombyx larvae and pupae to a temperature of $42^{\circ} \mathrm{C}$ or higher, much prevalent in tropical countries like India, greatly affects the ovarian development and reproductive performance of this commercially important insect. The study further showed a developmental- and tissue-specific expression of vitellogenin mRNA in fat body and ovary upon heat shock. When heat shock treatment was done at $39^{\circ} \mathrm{C}$ and $42^{\circ} \mathrm{C}$ to spinning larvae, ovary showed an upregulation in the expression of vitellogenin mRNA, whereas fat body failed to do so. However, at $45^{\circ} \mathrm{C}$, both fat body and ovary showed a downregulation. The heat shock treatment to day 2 pupae showed an upregulation in the vitellogenin mRNA expression in both fat body and ovary, even at $45^{\circ} \mathrm{C}$. The upregulation in the expression of vitellogenin upon heat shock indicates its role in thermal protection of Bombyx larvae and pupae.
\end{abstract}

\section{Introduction}

Global warming is one of the major challenges for the survival and reproduction of many life forms including insects. The increase of global mean surface temperature is likely to be $0.3-4.8^{\circ} \mathrm{C}$ by the end of 21 st century relative to $1986-2005$ [1]. It is warned that the heat waves will occur with a higher frequency and a longer duration [1]. Studies have shown that warmer temperatures associated with climate change can potentially affect insect species' population dynamics directly through effects on survival, generation time, fecundity, and dispersal $[2,3]$. Insects, being ectothermic organisms, are very likely to respond quickly to increased temperatures [4]. However the response of individual insect species will depend on their geographical range, trophic level, and natural history [3]. For majority of temperate insect species, increased temperature will allow them to extend their geographical range and enhance their population fitness [2]. However, for tropical insects, increased temperature is likely to have the most deleterious consequences as tropical insects are relatively sensitive to temperature change and are currently living very close to their optimal temperature [5]. Temperature above the optimum temperature is perceived as heat stress by all living organisms.

In a tropical country like India environmental factors such as temperature and humidity play a major role in the success of sericulture industry. Because of the extensive and careful domestication over centuries, the silkworm, Bombyx mori, is very much susceptible to abrupt temperature changes. Studies have shown that cells of all known organisms including B. mori respond to stress such as temperature by increased synthesis of heat shock or stress proteins (Hsps) [6-10]. Accumulation of these stress proteins induced by exposure to mild stress results in a transient state of stress resistance. It is indicated that heat inducible Hsps are important for heat induced hormesis in longevity and heat stress resistance in Drosophila [11]. Hormesis is the phenomenon where a mild exposure to an otherwise detrimental factor such as 
heat, insecticides, and radiation becomes beneficial for many organism and life history traits [12-15]. In Drosophila, a significant increase in lifespan of females, repeatedly exposed to mild heat stress through hormesis, has been suggested by Hercus et al. [16]. In the oriental fruit moth, Grapholita molesta, the exposure of females to a single heat event at $38^{\circ} \mathrm{C}$ for $4 \mathrm{~h}$ caused an increase in the lifespan and length of the oviposition period, leading to a potential increase in lifetime fecundity and suggesting hormesis [17]. However, Forbes [18] suggested that not all aspects of organism performance can be hormetic simultaneously and there might be an energetic trade-off among life history traits. Since both survival and reproduction require energy and since energy is limited, it is expected that there will be a trade-off between these two fitness components [19].

In B. mori, although literatures are available on the effect of heat stress on survival and expression of heat shock proteins $[8,20-25]$, little information is available on the effect of heat stress on its reproductive fitness. It is suggested that though the increased expression of heat shock proteins under mild heat stress plays an important role in helping insect to survive, its high level usually brings negative physiological effects on organisms [26]. The improved thermotolerance at the cost of reduced reproductive performance has been observed in many insect species such as Bicyclus anynana and Helicoverpa armigera [27-30]. In Spodoptera litura and Neoseiulus barkeri, mild thermal stress increases thermotolerance but brings a detrimental effect on fertility and fecundity $[26,31]$.

The developing ovary in Bombyx consists of four polytrophic meroistic ovarioles, each of which contains a long linear array of developing follicles in progressively advancing stage of development. Each follicle is surrounded by a layer of follicle cells and contains an oocyte and interconnected nurse cells. Vitellogenin, a precursor of major egg yolk protein, plays an important role in promoting the growth and differentiation of developing oocytes. The regulation of vitellogenin is directly under the control of hormones at the transcriptional level [32]. In Bombyx, its biosynthesis is regulated transcriptionally in a sex- and stage-dependent manner [33]. Vitellogenin functions not only as an energy reserve for the developing embryo but also in innate immune response [34]. Singh et al. [35] showed the antibacterial activity of vitellogenin and found that the infected silkworm larvae, treated with purified vitellogenin, survived the full life cycle in contrast to untreated animals. Increased vitellogenin expression in Caenorhabditis elegans potently increases their resistance against pathogenic bacteria and heat [36]. Recently Ihle et al. [37] showed that aging and lifespan in honey bees are affected by vitellogenin. This protein influences worker lifespan both as a regulator of behavioral maturation and through antioxidant and immune functions as an experimental reduction of vitellogenin expression resulted in decreased lifespan and increased susceptibility to oxidative damage.

Since development time and reproductive output of an insect are nearly as important to population growth as the survival of individuals, the present study has been carried out to investigate the consequences of heat stress on ovarian development and fecundity as well as on vitellogenin gene expression in B. mori.

\section{Material and Methods}

2.1. Insect. Silkworm (Bombyx mori) L. (CSR 18, a bivoltine race) was used for present study. Disease-free layings of silkworms breed CSR 18 were obtained from Central Sericultural Germplasm Resource Centre, CSB, Hosur, Tamil $\mathrm{Nadu}$, and reared with fresh mulberry leaves in laboratory under controlled conditions (temperature, $25 \pm 1^{\circ} \mathrm{C}$; humidity, $60-90 \%$, photoperiod, $12 \mathrm{~L}: 12 \mathrm{D})$. Larvae and pupae were staged according to days after ecdysis and the available morphological markers such as spinneret pigmentation and gut purge.

2.2. Heat Shock Treatment. For heat shock treatment, day 3 spinning larvae and day 2 pupae were placed individually in glass test tubes plugged with cotton and were submerged in a water bath at $39^{\circ} \mathrm{C}, 42^{\circ} \mathrm{C}$, and $45^{\circ} \mathrm{C}$ for $1 \mathrm{~h}$ and $2 \mathrm{~h}$, respectively, as described [38]. After the treatment, the larvae and pupae were returned to controlled laboratory conditions. Female larvae and pupae were considered for heat shock treatment. Male silkworm larvae and pupae were subjected to heat shock treatment only for the purpose of copulation.

2.3. Determination of Gonadosomatic Index. Heat shock was given to day 2 female pupae and developing ovaries were dissected out after $48 \mathrm{~h}$ (day 4), $96 \mathrm{~h}$ (day 6), and $144 \mathrm{~h}$ (day 8) of heat shock treatment. The isolated ovaries were rinsed with insect ringer solution, blotted dry with filter paper, and the weight was measured using digital weighing balance. Gonadosomatic index (GSI) was calculated using the equation GSI = ovary wet weight $(\mathrm{g}) /$ total body weight $(\mathrm{g}) \times$ 100 [39]. The experiments were repeated 2-3 times and mean value of GSI was calculated for each experimental group from the data obtained from 6-8 individuals.

2.4. Estimation of Fecundity. Day 3 spinning larvae and day 2 pupae (both males and females) were subjected to heat shock treatment and the adult moths were collected for mating. The moths were allowed to copulate for $5 \mathrm{~h}$ and afterwards the moths were decoupled and the females were kept for oviposition and males were disposed off. The fecundity was calculated by counting the number of eggs laid by each female within $24 \mathrm{~h}$ time period. The experiments were repeated 3 times and the mean value of fecundity was calculated from the data obtained from 10-12 individuals.

2.5. RNA Isolation and Semiquantitative RT-PCR. The fat body and ovary were dissected out from 5 th instar larvae and pupae under cold insect ringer solution and homogenized immediately in TRIzol reagent (Invitrogen) and stored at $-70^{\circ} \mathrm{C}$. Total RNA was isolated according to the manufacturer's protocol. The concentration of RNA was measured spectrophotometrically at $260 \mathrm{~nm}$. The purity of the total RNA was assessed using $A_{260 / 280}$ ratios. Denaturing agarose 

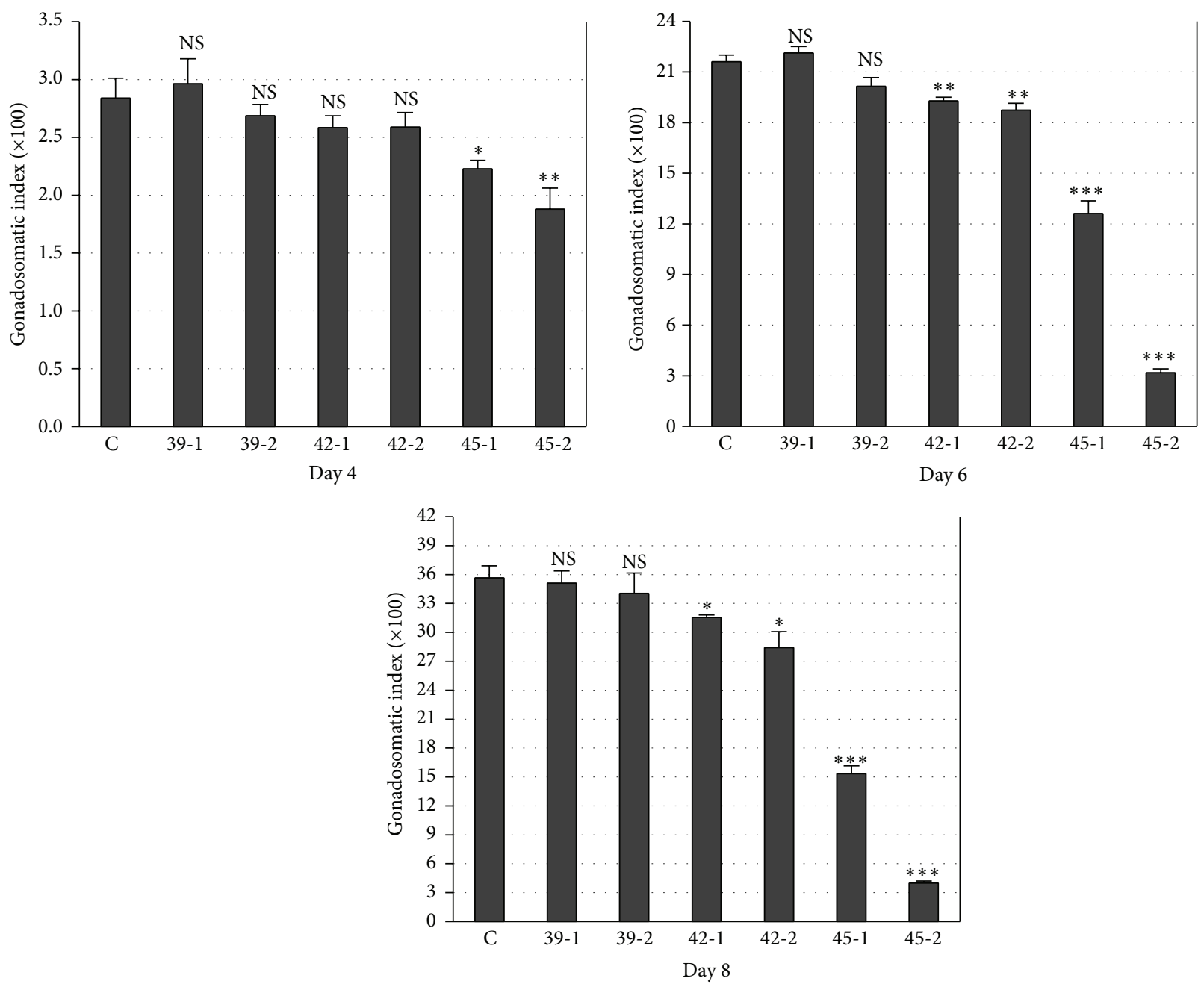

FIGURE 1: Effect of heat stress on gonadosomatic index (ovary). Heat shock was given to pupae, 2 days after larval-pupal ecdysis and developing ovarioles were dissected out from pupae on days 4, 6 , and 8 from each experimental group. The wet weight of developing ovaries was measured after rinsing with insect ringer solution and gonadosomatic index was calculated with respect to total body weight. Each histogram bar represents the mean gonadosomatic index $(n=6-8)$ and the error bar represents standard error of the mean (SEM). The asterisks show the data which are significantly different from control sample (unpaired $t$-test; ${ }^{*} p<0.05,{ }^{* *} p<0.01$, and ${ }^{* * *} p<0.001$ ). NS: not significant at $p<0.05$. C: control; $39-1$ : heat shock at $39^{\circ} \mathrm{C}$ for $1 \mathrm{~h} ; 39-2$ : heat shock at $39^{\circ} \mathrm{C}$ for $2 \mathrm{~h} ; 42-1$ : heat shock at $42^{\circ} \mathrm{C}$ for $1 \mathrm{~h} ; 42-2$ : heat shock at $42^{\circ} \mathrm{C}$ for $2 \mathrm{~h}$; $45-1$ : heat shock at $45^{\circ} \mathrm{C}$ for $1 \mathrm{~h} ; 45-2$ : heat shock at $45^{\circ} \mathrm{C}$ for $2 \mathrm{~h}$.

gel electrophoresis was performed to ascertain the integrity of isolated RNA.

The cDNA was synthesized from total RNA using MMLV reverse transcriptase (Invitrogen) and oligo dT 18 primers (Integrated DNA Technologies, Inc.) following manufacturer's protocol. The cDNA was subsequently used for amplification of target DNA by Polymerase Chain Reaction (PCR) using the gene specific forward and reverse primers. Forward and reverse primers for vitellogenin and ribosomal protein (rp49) were designed based on the sequence data available on Genbank. For vitellogenin (Accession number: NM_001043844) the forward primer and reverse primers are $5^{\prime}$-GCTTTGCCTAGGACCCTACG-3' and $5^{\prime}$ GCAGCGGACTTAAAAGCAACC- $3^{\prime}$ and for rp49 (Accession number: $\mathrm{AB}$ 048205) the forward primer and reverse primers are $5^{\prime}$-GCATCAATCGGATCGCTATGAC- $3^{\prime}$ and
$5^{\prime}$-CAAGAAGACCCGTCATATGCT-3'. Briefly, the samples were heated at $95^{\circ} \mathrm{C}$ for $10 \mathrm{~min}$ followed by 30 amplification cycles $\left(95^{\circ} \mathrm{C}\right.$ for $30 \mathrm{~s}, 60^{\circ} \mathrm{C}$ for $30 \mathrm{~s}$, and $72^{\circ} \mathrm{C}$ for $\left.45 \mathrm{~s}\right)$ and a final 10 minutes extension period at $72^{\circ} \mathrm{C}$. The amplified products were subjected to $3.5 \%$ agarose gel electrophoresis and molecular size was confirmed by running DNA standard. Images of the RT-PCR ethidium bromide-stained gel were acquired and quantification of the band densities was performed using Image-J program. The experiments were repeated 2-3 times with 2-3 independent biological replicates in each experiment. For data normalization, $r p 49$ was used as a reference gene. The transcript level of the vitellogenin gene was calculated relative to $r p 49$ expression for each sample by comparing the band densities. The normalized value of vitellogenin mRNA expression level in one of the control samples was designated as 1 and afterwards the relative 


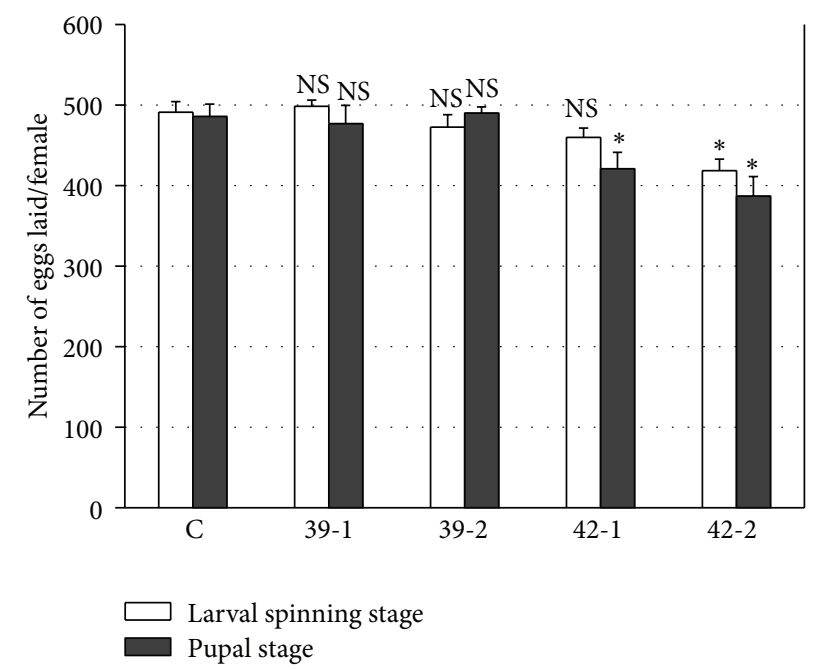

FIGURE 2: Effect of heat stress on fecundity. Heat shock was given to spinning larvae and day 2 pupae and number of eggs laid per female was counted from each experimental group. Each histogram bar represents the mean value for fecundity $(n=10-12)$ and the error bar represents standard error of the mean (SEM). The asterisks show the data which are significantly different from control sample (unpaired $t$-test; ${ }^{*} p<0.01$ ). The abbreviations used are as mentioned for Figure 1.

expression levels for the remaining control samples and the experimental samples were calculated. Mean and SEM were obtained using relative expression level values for control and all experimental groups.

2.6. Statistical Analysis. Student'st-test was performed for the analysis of the data using GraphPad Prism 6 software.

\section{Results}

3.1. Effect of Heat Stress on Ovarian Development and GSI. Gonadosomatic index is an important indicator to show the gonadal developmental progress and its maturity. In the present study, Bombyx ovary showed an increase in GSI with the advancement of ovarian development during pupal stage. The GSI increased from $2.8 \pm 0.2$ to $21.6 \pm 0.4$ from day 4 to day 6 of pupal life (Figure 1). On day 8, GSI increased to $35.6 \pm 1.3$. The mild heat shock treatment to day 2 pupae at $39^{\circ} \mathrm{C}(1 \mathrm{~h}$ and $2 \mathrm{~h})$ failed to show any adverse effect on GSI. However, the heat shock treatment at $42^{\circ} \mathrm{C}$ and $45^{\circ} \mathrm{C}$ caused a severe effect on GSI. The heat shock exposure at $42^{\circ} \mathrm{C}(1 \mathrm{~h}$ and $2 \mathrm{~h}$ ) caused a significant decrease $(p<0.05-0.01)$ in GSI, as observed on day 6 and day 8 of pupal life (Figure 1). The heat shock treatment at $45^{\circ} \mathrm{C}$ showed a more severe effect than $42^{\circ} \mathrm{C}$ and even day 4 pupae showed a decrease in GSI (Figure 1). With $1 \mathrm{~h}$ exposure at $45^{\circ} \mathrm{C}$, a decrease in GSI to $12.6 \pm 0.7$ and $15.3 \pm 0.8$ was observed on day 6 and day 8 , respectively (Figure 1 ). With the increase of heat shock duration to $2 \mathrm{~h}$ at $45^{\circ} \mathrm{C}$, a drastic decrease in GSI to $3.2 \pm 0.23$ and $4.0 \pm 0.2$ was observed on day 6 and day 8 of pupal life, respectively (Figure 1).
3.2. Effect of Heat Stress on Fecundity. The heat shock treatment to either spinning larvae or day 2 pupae at $39^{\circ} \mathrm{C}$ failed to bring any adverse effect on the fecundity of the adult female moth (Figure 2). However, the heat shock treatment at $42^{\circ} \mathrm{C}$ caused a significant decrease in fecundity. The heat shock exposure to day 2 pupae for $1 \mathrm{~h}$ at $42^{\circ} \mathrm{C}$ caused a decrease in fecundity to $421 \pm 20$ from $491 \pm 12$, observed for untreated adult moth (Figure 2). A $2 \mathrm{~h}$ exposure at this temperature showed a further decrease in fecundity to $387 \pm 24$. For spinning larvae, the heat shock treatment at $42^{\circ} \mathrm{C}$ for $1 \mathrm{~h}$ did not show any significant changes in the fecundity of the survived adult. However, the exposure to spinning larvae for $2 \mathrm{~h}$ at this temperature caused a significant decrease in fecundity to $418 \pm 14$ (Figure 2). The fecundity data could not be measured for experimental group, heat stressed at $45^{\circ} \mathrm{C}$, as this treatment caused death of the most of the heat stressed individual, although the heat stressed pupae could survive for few days, as evident by a response to a stimulus like touch [25].

\subsection{Effect of Heat Stress on Vitellogenin mRNA Expression.} The heat shock treatment to spinning larvae and pupae showed a developmental- and tissue-specific expression of vitellogenin mRNA in fat body and ovary. The heat shock treatment to spinning larvae at mild and mild-to-severe heat stressed condition $\left(39^{\circ} \mathrm{C}\right.$ and $\left.42^{\circ} \mathrm{C}\right)$ showed a significant increase in vitellogenin mRNA expression level but only in ovary (Figure 3(b)) and not in fat body (Figure 3(a)). However, at severe-to-lethal heat stressed condition $\left(45^{\circ} \mathrm{C}\right)$, ovary showed a significant decrease in vitellogenin expression (Figure 3(b)). The fat body tissues also showed a decrease in vitellogenin expression at this temperature but only for a $2 \mathrm{~h}$ exposure (Figure 3(a)).

The heat shock treatment to day 2 pupae showed an unexpected but a very promising result on vitellogenin mRNA expression level. In both fat body and ovary, an increase in vitellogenin mRNA expression was observed upon heat shock treatment even at severe-to-lethal heat stressed condition $\left(45^{\circ} \mathrm{C}\right)$ (Figures 4(a) and 4(b)). It should be noted that the heat stressed pupae at $45^{\circ} \mathrm{C}$ could survive for many days after the heat shock treatment, although they could not emerge as adults. In day 4 pupae, however, vitellogenin expression in both fat body and ovary tissues decreased to almost control level, except at $45^{\circ} \mathrm{C}, 2 \mathrm{~h}$, where a downregulation in vitellogenin expression was observed (Figure 4(c)).

\section{Discussion}

Our previous study [25] showed an increased expression of heat shock protein 90 (hsp90) in Bombyx larvae and pupae upon mild heat shock treatment at $39^{\circ} \mathrm{C}$. The study further suggested that the upregulation of hsp90 at a particular heat shock temperature is associated with the ability of the animal to survive upon heat stress. The present study showed that heat shock to Bombyx larvae and pupae at mild temperature $\left(39^{\circ} \mathrm{C}\right)$ is without any adverse effect on ovarian development and fecundity. Thus, the ability of silkworm larvae and pupae to withstand heat stress at mild temperature apparently with 

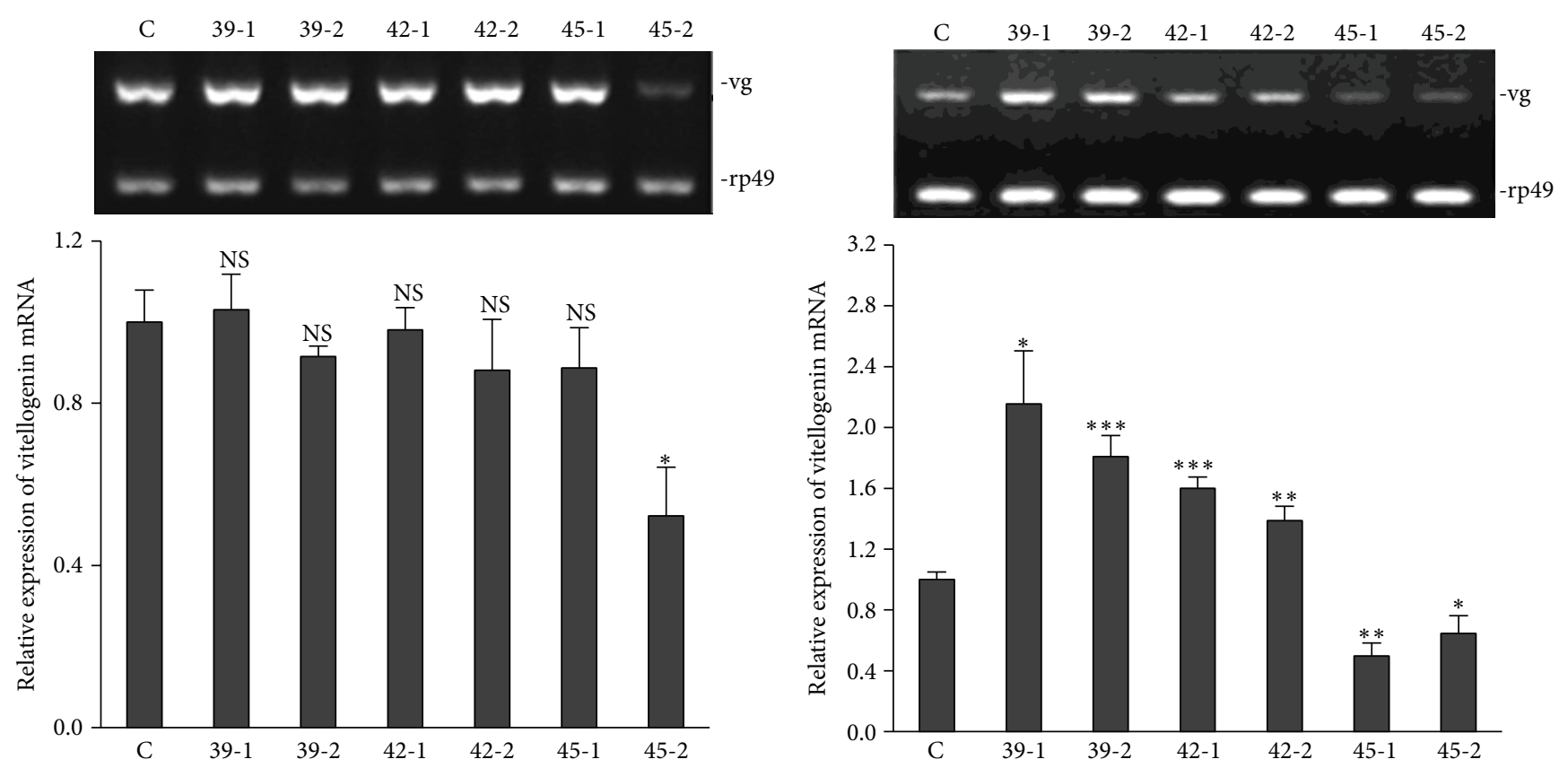

(a)

(b)

FIGURE 3: Vitellogenin mRNA expressions in spinning larvae upon heat shock. (a) Fat body. (b) Ovary. The upper panel showed expression of vitellogenin and rp49 as revealed by semiquantitative RT-PCR. The lower panel showed relative expression level of vitellogenin. The transcript level of the vitellogenin gene was calculated relative to rp49 expression for each sample. Each histogram bar represents the mean relative expression of vitellogenin $(n=5-7)$ and the error bar represents standard error of the mean (SEM). The asterisks show the data which are significantly different from control sample (unpaired $t$-test; ${ }^{*} p<0.05,{ }^{* *} p<0.01$, and ${ }^{* * *} p<0.001$ ). The abbreviations used are as mentioned for Figure 1.

no reproductive cost seems to be positively related with an increased expression of hsp90. Sarup et al. [40] suggested that the mild heat shock treatment might induce hormetic response as this treatment upregulates the synthesis of Hsps and extends the lifespan in Drosophila.

The heat shock treatment to Bombyx larvae and pupae at a temperature of $42^{\circ}$ was not lethal for their survival, and majority of them after heat shock treatment entered into normal developmental program [25]. The heat shock at this temperature also induced the expression of hsp90 [25]. The present study showed that the heat shock exposure to Bombyx larvae and pupae at this temperature affects their ovarian development and reproductive performance as evident from decreased gonadosomatic index and fecundity. A "trade-off" thus exists between thermal resistance and reproduction in B. mori. In D. melanogaster, repeated mild heat stress caused increased thermotolerance but also brought a detrimental effect on fertility and fecundity [16]. In D. virilis, heat stress results in oocyte maturation delays, degradation of early vitellogenic egg chambers, and inhibition of yolk protein gene expression in follicle cells and accumulation of mature oocytes [41]. Heat shock also had deleterious effects on ovarian development in Tribolium castaneum [42], on fecundity in Trialeurodes vaporariorum and Liriomyza huidobrensis [27, $43]$, and on differentiation of the apyrene spermatozoa in Bombyx [44].

The vitellogenin mRNA showed a tissue- and developmental-specific expression upon heat shock treat- ment during larval spinning and pupal stages. In larval ovary, the heat shock at $39^{\circ} \mathrm{C}$ and $42^{\circ} \mathrm{C}$ caused an increase in vitellogenin mRNA expression, but with the increase of heat shock temperature to $45^{\circ} \mathrm{C}$, a downregulation in its expression was observed. This pattern of upregulation of vitellogenin mRNA expression in larval ovary followed the same trend as was observed for hsp90 mRNA expression [25]. The induction of vitellogenin mRNA expression in larval ovary upon mild heat stress when the larvae could survive and molted to pupae indicates that vitellogenin might have a protective role in the survival of $B$. mori and thus suggests its role in hormesis like hsp90. The increased expression of vitellogenin might also help the differentiating tissues like ovary at spinning stage to cope up with the challenged situation, raised because of the heat shock treatment.

The data on the increased expression of vitellogenin mRNA upon heat shock treatment even at $45^{\circ} \mathrm{C}$ during pupal stage further support its protective action. It has to be noted that when heat shock was given at a temperature of $45^{\circ} \mathrm{C}$, the pupae could survive for many days, although it could not eclose. An upregulation in the expression of vitellogenin with an increased magnitude of heat shock treatment is difficult to explain now but a detailed mechanistic study in future can explain the differential expression of vitellogenin upon heat shock. It is also difficult to hypothesize that the induction of vitellogenin upon heat shock treatment involves insect hormones, although it is quite known that the vitellogenesis in insects including B. mori is under the direct regulation of 


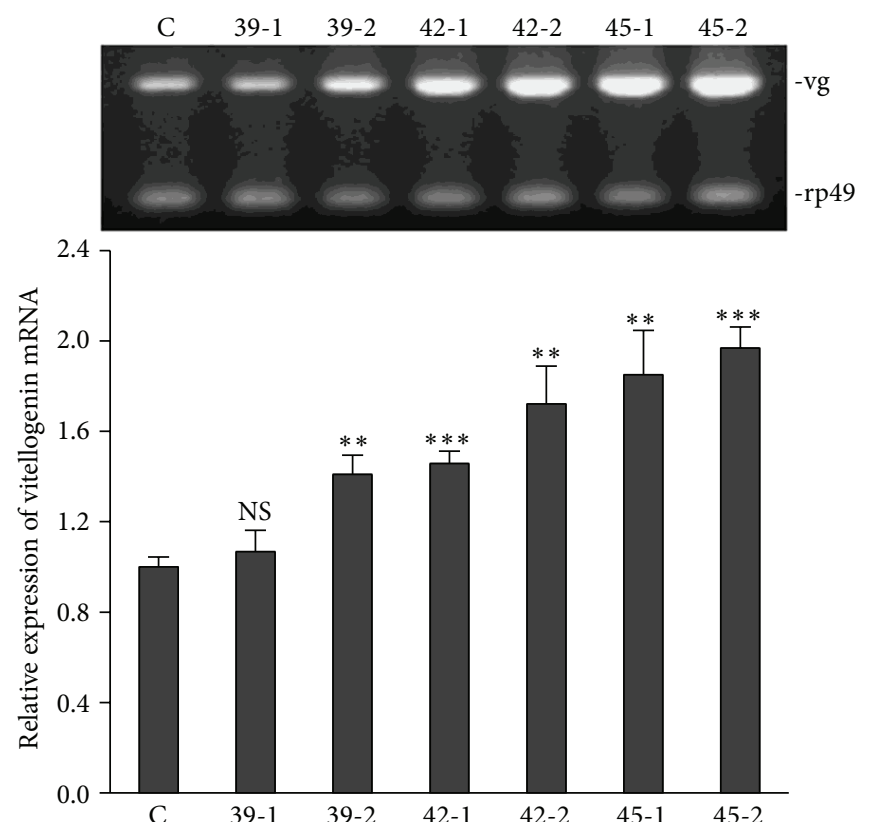

(a)
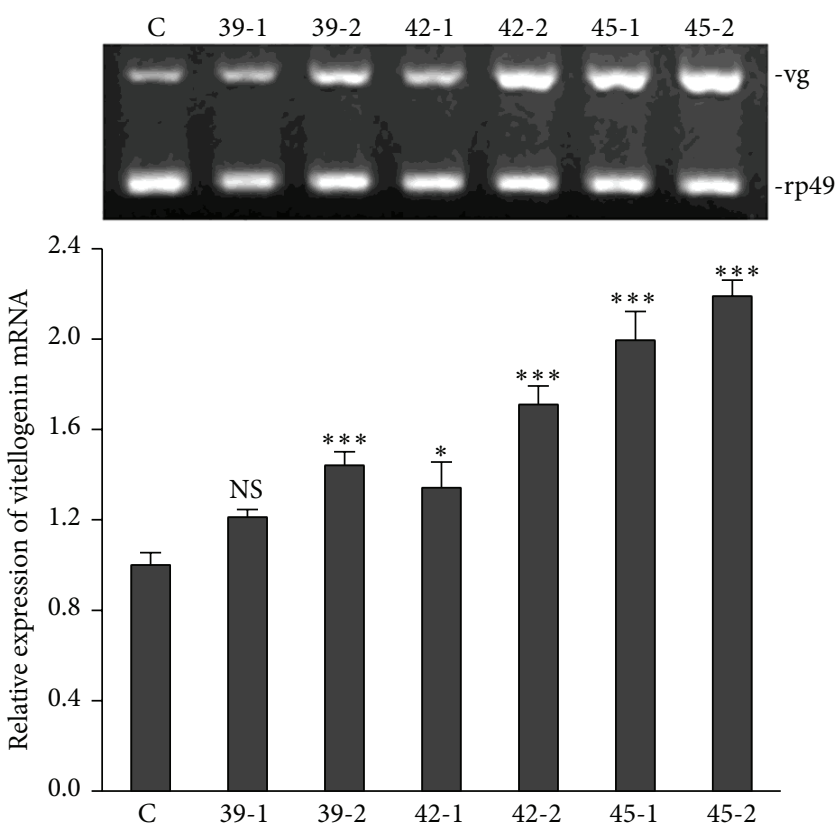

(b)

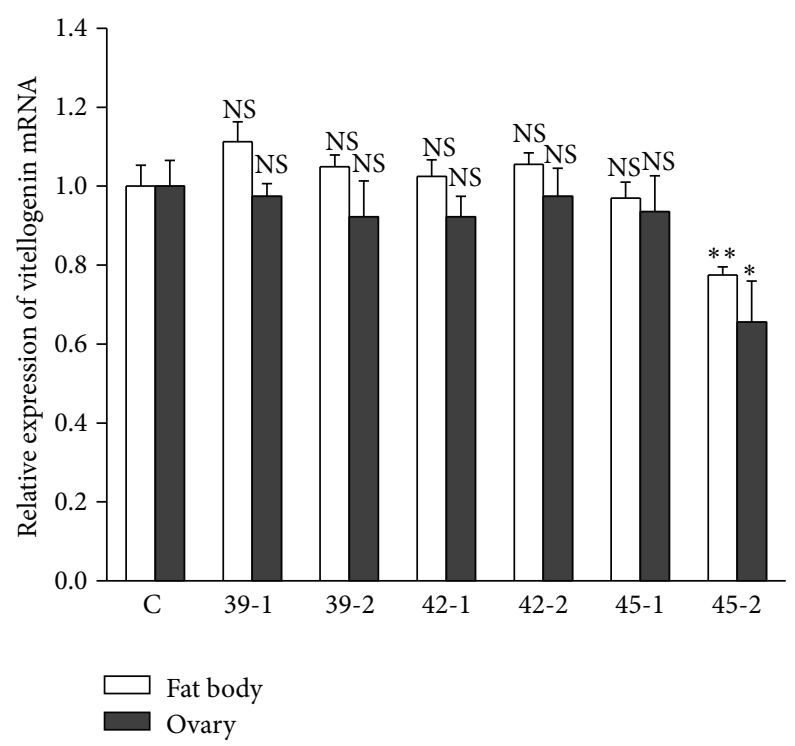

(c)

FIGURE 4: Vitellogenin mRNA expressions in pupae. (a) Fat body, day 2 pupae. (b) Ovary, day 2 pupae. (c) Fat body and ovary, day 4 pupae. The upper panel showed expression of vitellogenin and rp49 as revealed by semiquantitative RT-PCR. The lower panel showed relative expression level of vitellogenin as normalized with rp49 transcript level. Each histogram bar represents the mean relative expression of vitellogenin $(n=5-7)$ and the error bar represents standard error of the mean (SEM). The asterisks show the data which are significantly different from control sample (unpaired $t$-test; ${ }^{*} p<0.05,{ }^{* *} p<0.01$, and ${ }^{* * *} p<0.001$ ). The abbreviations used are as mentioned for Figure 1.

insect hormones like juvenile hormone and/or ecdysteroids. Thus, the possibility remains that heat shock might have disrupted the normal hormonal milieu in Bombyx and thereby changed the vitellogenin expression in the fat body and ovary. Teixeira and polavarapu [45] showed that heat stress inhibits the completion of pupal diapause in Rhagoletis mendax and suggested that the failure to complete the development was due to the damage of the endocrine system by heat stress as the application of exogenous 20-hydroxyecdysone on these pupae caused them to develop to the adult stage.

The data further suggests that vitellogenin expression is temperature-dependent as in pupae, after the first significant increase as observed within $1 \mathrm{~h}$ of heat shock treatment, its expression returned to normal expression level at $48 \mathrm{~h}$ of heat shock treatment, except at $45^{\circ} \mathrm{C}$, where a downregulation in its expression was observed. Thus, the 
temperature-dependent variations in the expression of vitellogenin indicate its role in thermal protection of silkworm larvae and pupae besides its classical role as a precursor of egg yolk proteins. Although information regarding the other functional aspects of vitellogenin is not available much but limited literature showed its hemagglutinating and antibacterial activities [34]. The antibacterial activity of vitellogenin has been demonstrated in Bombyx, and it is shown that infected silkworm larvae, treated with vitellogenin, survived the full life cycle in contrast to untreated animals [35]. Vitellogenin also has the protective role against oxidative stress. It is synthesized at high levels in honey bee queens and is abundant in long-lived worker, protecting the sterile honey bee workers from oxidative stress [46]. Increased vitellogenin expression in $C$. elegans potently increases their resistance against heat [36]. Ihle et al. [37] showed that an experimental reduction of vitellogenin expression in honey bees resulted in decreased lifespan and increased susceptibility to oxidative damage.

In conclusion, the study hypothesizes that vitellogenin might have a protective role on the survival of silkworm. Further, a brief exposure of Bombyx larvae and pupae to a temperature of $42^{\circ} \mathrm{C}$ or higher (which is very common in tropical countries) greatly affects the ovarian development and reproductive performance of this commercially important insect. Further studies can be undertaken to know the mechanism of regulation of vitellogenin expression under heat stress in B. mori and other organisms and its protective role by interfering with its synthesis.

\section{Competing Interests}

The authors declare that they have no competing interests.

\section{Acknowledgments}

This study was supported by Department of Science and Technology (DST), Government of India, a project under SERC FAST Track Scheme (SR/FT/LS-026/2008) for Young Scientist sanctioned to Bela Keshan. Thanks are to the Director, Central Sericultural Germplasm Resource Centre (CSGRC), CSB, Hosur, Tamil Nadu, India, for providing to the authors disease-free layings (dfls) of silkworm.

\section{References}

[1] Intergovernmental Panel on Climate Change (IPCC), Climate Change: Synthesis Report; Summary for Policymakers, 2014, https://www.ipcc.ch/pdf/assessment-report/ar5/syr/AR5_SYR_ FINAL_SPM.pdf.

[2] J. S. Bale, G. J. Masters, I. D. Hodkinson et al., "Herbivory in global climate change research: direct effects of rising temperature on insect herbivores," Global Change Biology, vol. 8, no. 1, pp. 1-16, 2002.

[3] E. E. Stange and M. P. Ayres, "Climate change impacts: insects," in $e L S$, John Wiley \& Sons, Chichester, UK, 2010.

[4] C. Robinet and A. Roques, "Direct impacts of recent climate warming on insect populations," Integrative Zoology, vol. 5, no. 2, pp. 132-142, 2010.
[5] C. A. Deutsch, J. J. Tewksbury, R. B. Huey et al., "Impacts of climate warming on terrestrial ectotherms across latitude," Proceedings of the National Academy of Sciences of the United States of America, vol. 105, no. 18, pp. 6668-6672, 2008.

[6] M. E. Feder and G. E. Hofmann, "Heat-shock proteins, molecular chaperones, and the stress response: evolutionary and ecological physiology," Annual Review of Physiology, vol. 61, pp. 243-282, 1999.

[7] L.-H. Huang, H.-S. Wang, and L. Kang, "Different evolutionary lineages of large and small heat shock proteins in eukaryotes," Cell Research, vol. 18, no. 10, pp. 1074-1076, 2008.

[8] J. Li, S. H. H. Moghaddam, X. Du, B.-X. Zhong, and Y.-Y. Chen, "Comparative analysis on the expression of inducible HSPs in the silkworm, Bombyx mori," Molecular Biology Reports, vol. 39, no. 4, pp. 3915-3923, 2012.

[9] J. G. Sørensen, T. N. Kristensen, and V. Loeschcke, "The evolutionary and ecological role of heat shock proteins," Ecology Letters, vol. 6, no. 11, pp. 1025-1037, 2003.

[10] L. Zhao and W. A. Jones, "Expression of heat shock protein genes in insect stress responses," Invertebrate Survival Journal, vol. 9, pp. 93-101, 2012.

[11] J. G. Sørensen, T. N. Kristensen, K. V. Kristensen, and V. Loeschcke, "Sex specific effects of heat induced hormesis in Hsfdeficient Drosophila melanogaster," Experimental Gerontology, vol. 42, no. 12, pp. 1123-1129, 2007.

[12] J. R. Cypser, P. Tedesco, and T. E. Johnson, "Hormesis and aging in Caenorhabditis elegans," Experimental Gerontology, vol. 41, no. 10, pp. 935-939, 2006.

[13] E. Le Bourg and N. Minois, "Increased longevity and resistance to heat shock in Drosophila melanogaster flies exposed to hypergravity," Comptes Rendus de l Académie des Sciences, Série 3: Sciences de la Vie, vol. 320, pp. 215-221, 1997.

[14] N. Minois, "Longevity and aging: beneficial effects of exposure to mild stress," Biogerontology, vol. 1, no. 1, pp. 15-29, 2000.

[15] P. A. Parsons, "Hormesis: an adaptive expectation with emphasis on ionizing radiation," Journal of Applied Toxicology, vol. 20, no. 2, pp. 103-112, 2000.

[16] M. J. Hercus, V. Loeschcke, and S. I. S. Rattan, "Lifespan extension of Drosophila melanogaster through hormesis by repeated mild heat stress," Biogerontology, vol. 4, no. 3, pp. 149156, 2003.

[17] L. N. Liang, W. Zhang, G. Ma, A. A. Hoffmann, C. Ma, and R. N. Guedes, "A single hot event stimulates adult performance but reduces egg survival in the oriental fruit moth, Grapholitha molesta," PLoS ONE, vol. 9, no. 12, Article ID e116339, 2014.

[18] V. E. Forbes, "Is hormesis an evolutionary expectation?" Functional Ecology, vol. 14, no. 1, pp. 12-24, 2000.

[19] P. Calow and R. M. Sibly, "A physiological basis of population processes: ecotoxicological implications," Functional Ecology, vol. 4, no. 3, pp. 283-288, 1990.

[20] O. Joy and K. P. Gopinathan, "Heat shock response in mulberry silkworm races with different thermotolerances," Journal of Biosciences, vol. 20, no. 4, pp. 499-513, 1995.

[21] V. B. Chavadi, A. H. Sosalegowda, and M. H. Boregowda, "Impact of heat shock on heat shock proteins expression, biological and commercial traits of Bombyx mori," Insect Science, vol. 13, no. 4, pp. 243-250, 2006.

[22] H. B. Manjunatha, R. K. Rajesh, and H. S. Aparna, "Silkworm thermal biology: a review of heat shock response, heat shock proteins and heat acclimation in the domesticated silkworm, Bombyx mori," Journal of Insect Science, vol. 10, article 204, 2010. 
[23] A. H. Sosalegowda, R. R. Kundapur, and M. H. Boregowda, "Molecular characterization of heat shock proteins 90 (HSP83?) and 70 in tropical strains of Bombyx mori," Proteomics, vol. 10, no. 15, pp. 2734-2745, 2010.

[24] V. K. Rahmathulla, C. M. K. Kumar, B. S. Angadi, and V. Sivaprasad, "Association of climatic factors on population dynamics of leaf roller, Diaphania pulverulentalis hampson (Lepidoptera: Pyralidae) in mulberry plantations of sericulture seed farm," Psyche, vol. 2012, Article ID 186214, 6 pages, 2012.

[25] B. Keshan, S. Paul, T. Bembem, and S. D. Kh, “Tissue-specific expression patterns of heat shock protein 90 transcripts in silkworm, Bombyx Mori," Journal of Entomology and Zoology Studies, vol. 2, no. 6, pp. 53-59, 2014.

[26] Y. Shen, Y.-J. Gong, J. Gu, L.-H. Huang, and Q.-L. Feng, "Physiological effect of mild thermal stress and its induction of gene expression in the common cutworm, Spodoptera litura," Journal of Insect Physiology, vol. 61, no. 1, pp. 34-41, 2014.

[27] L.-H. Huang, B. Chen, and L. Kang, "Impact of mild temperature hardening on thermotolerance, fecundity, and Hsp gene expression in Liriomyza huidobrensis," Journal of Insect Physiology, vol. 53, no. 12, pp. 1199-1205, 2007.

[28] T. L. Geister, M. W. Lorenz, M. Meyering-Vos, K. H. Hoffmann, and K. Fischer, "Effects of temperature on reproductive output, egg provisioning, juvenile hormone and vitellogenin titres in the butterfly Bicyclus anynana," Journal of Insect Physiology, vol. 54, no. 8, pp. 1253-1260, 2008.

[29] G. K. Mironidis and M. Savopoulou-Soultani, "Effects of heat shock on survival and reproduction of Helicoverpa armigera (Lepidoptera: Noctuidae) adults," Journal of Thermal Biology, vol. 35, no. 2, pp. 59-69, 2010.

[30] S. A. Janowitz and K. Fischer, "Opposing effects of heat stress on male versus female reproductive success in Bicyclus anynana butterflies," Journal of Thermal Biology, vol. 36, no. 5, pp. 283287, 2011.

[31] G. H. Y. Zhang, Y. Y. Li, K. J. Zhang, J. J. Wang, Y. Q. Liu, and H. Liu, "Effects of heat stress on copulation, fecundity and longevity of newly-emerged adults of the predatory mite, Neoseiulus barkeri (acari: phytoseiidae)," Systematic and Applied Acarology, vol. 21, no. 3, pp. 295-306, 2016.

[32] M. Tufail, Y. Nagaba, A. M. Elgendy, and M. Takeda, "Regulation of vitellogenin genes in insects," Entomological Science, vol. 17, no. 3, pp. 269-282, 2014.

[33] K.-I. Yano, M. T. Sakurai, S. Izumi, and S. Tomino, "Vitellogenin gene of the silkworm, Bombyx mori: structure and sexdependent expression," FEBS Letters, vol. 356, no. 2-3, pp. 207211, 1994.

[34] S. Zhang, S. Wang, H. Li, and L. Li, "Vitellogenin, a multivalent sensor and an antimicrobial effector," International Journal of Biochemistry and Cell Biology, vol. 43, no. 3, pp. 303-305, 2011.

[35] N. K. Singh, B. C. Pakkianathan, M. Kumar et al., "Vitellogenin from the Silkworm, Bombyx mori: an effective anti-bacterial agent," PLoS ONE, vol. 8, article e73005, 2013.

[36] M. Fischer, C. Regitz, M. Kahl, M. Werthebach, M. Boll, and U. Wenzel, "Phytoestrogens genistein and daidzein affect immunity in the nematode Caenorhabditis elegans via alterations of vitellogenin expression," Molecular Nutrition and Food Research, vol. 56, no. 6, pp. 957-965, 2012.

[37] K. E. Ihle, O. Rueppell, Z. Y. Huang et al., "Genetic architecture of a hormonal response to gene knockdown in honey bees," Journal of Heredity, vol. 106, no. 2, pp. 155-165, 2015.

[38] C. M. Fittinghoff and L. M. Riddiford, "Heat sensitivity and protein synthesis during heat-shock in the tobacco hornworm,
Manduca sexta," Journal of Comparative Physiology B: Biochemical Systemic and Environmental Physiology, vol. 160, no. 4, pp. 349-356, 1990.

[39] B. J. Barber and N. J. Blake, "Reproductive physiology," in Scallops: Biology, Ecology, and Aquaculture, S. E. Shumway and G. J. Parsons, Eds., pp. 357-e416, Elsevier, Amsterdam, The Netherlands, 2006.

[40] P. Sarup, P. Sørensen, and V. Loeschcke, "The long-term effects of a life-prolonging heat treatment on the Drosophila melanogaster transcriptome suggest that heat shock proteins extend lifespan," Experimental Gerontology, vol. 50, pp. 34-39, 2014.

[41] N. E. Gruntenko, M. Bownes, J. Terashima, M. Z. Sukhanova, and I. Y. Raushenbach, "Heat stress affects oogenesis differently in wild-type Drosophila virilis and a mutant with altered juvenile hormone and 20-hydroxyecdysone levels," Insect Molecular Biology, vol. 12, no. 4, pp. 393-404, 2003.

[42] J. Xu, J. Shu, X. Qiu et al., "Effects of heat shock on ovary development and hsp83 expression in Tribolium castaneum (Coleoptera: Tenebrionidae)," Archives of Insect Biochemistry and Physiology, vol. 70, no. 3, pp. 204-216, 2009.

[43] X. Cui, F. Wan, M. Xie, and T. Liu, "Effects of heat shock on survival and reproduction of two whitefly species, Trialeurodes vaporariorum and Bemisia tabaci biotype B," Journal of Insect Science, vol. 8, article 24, 2008.

[44] H. Fugo, M. Yamauchi, and S. G. Dedos, “Testicular ecdysteroid level in the silkmoth, Bombyx mori, with special reference to heat treatment during the wandering stage," Zoological Science, vol. 12, no. 6, pp. 783-788, 1995.

[45] L. A. F. Teixeira and S. Polavarapu, "Heat stress inhibits the completion of pupal diapause in Rhagoletis mendax (Diptera: Tephritidae)," Annals of the Entomological Society of America, vol. 98, no. 2, pp. 197-204, 2005.

[46] S.-C. Seehuus, K. Norberg, U. Gimsa, T. Krekling, and G. V. Amdam, "Reproductive protein protects functionally sterile honey bee workers from oxidative stress," Proceedings of the National Academy of Sciences of the United States of America, vol. 103, no. 4, pp. 962-967, 2006. 

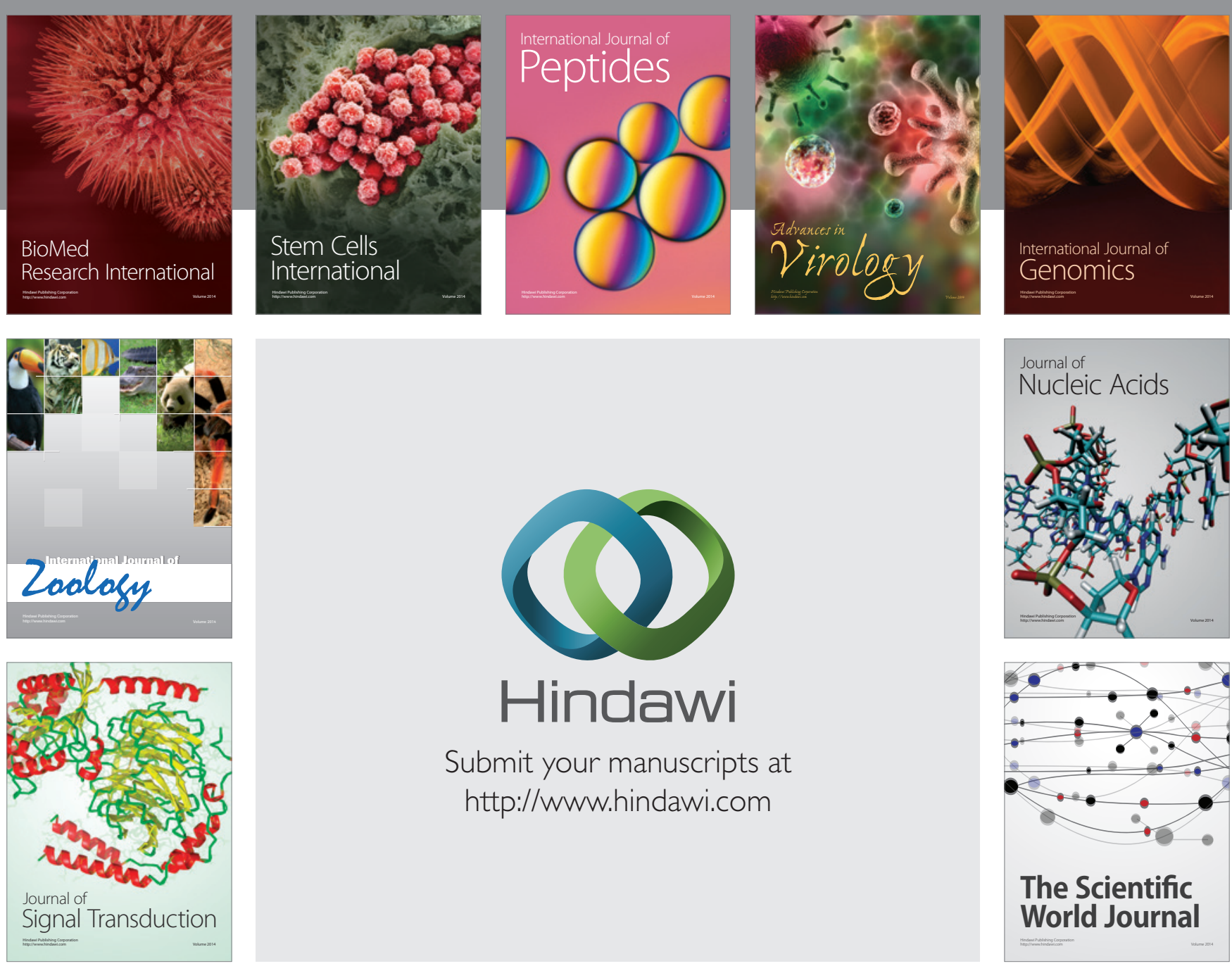

Submit your manuscripts at

http://www.hindawi.com
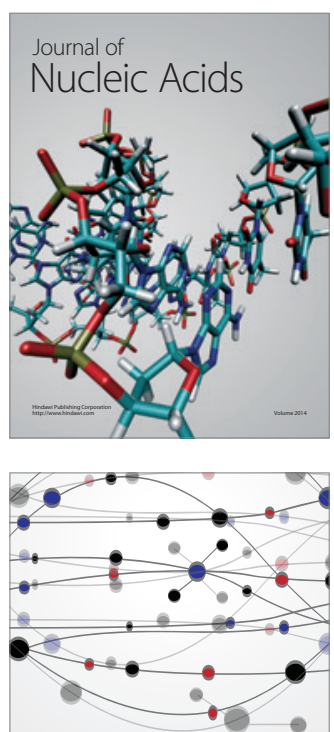

The Scientific World Journal
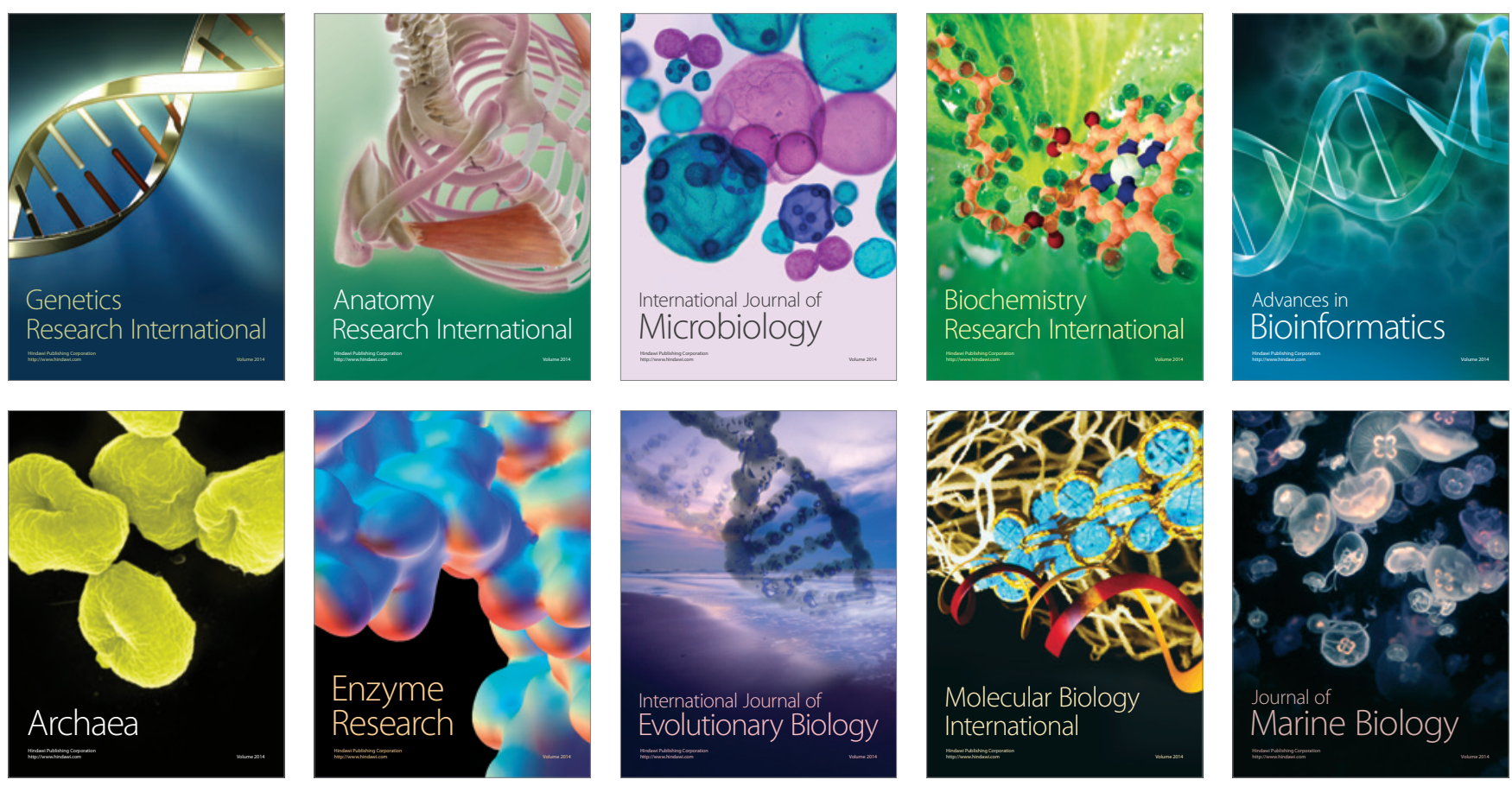